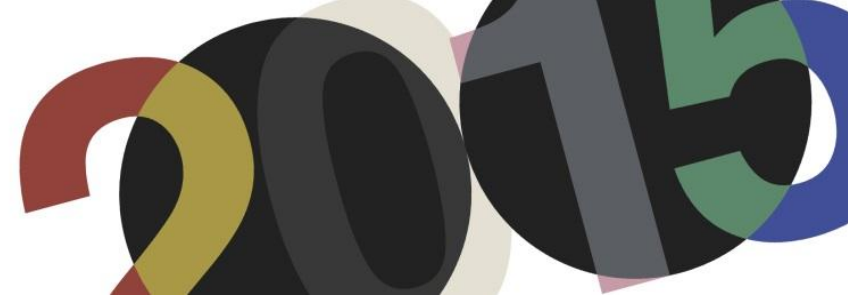

DOI: http://dx.doi.org/10.4995/LC2015.2015.784

\title{
Le Corbusier in Chandigarh: A Search for the Natural Order
}

\author{
A. Ramesh \\ Department of Architecture and Planning, Visvesvaraya National Institute of Technology, Nagpur, India
}

\begin{abstract}
This paper is an attempt to analyse and decode Le Corbusier's application of his exceptionally singular and complex understanding of the order of the natural world in his urban masterpiece-Chandigarh City. It was Le Corbusier's strong belief that architecture was a personal search for truth, a truth that was contained in the organic harmony of nature. He was convinced that with the advent of the machine in the $19 t^{h}$ century, ties between man and nature had been severed. For the sake of the citizen's physiological and psychological health, he felt it was essential that future cities focus on reconnecting man to nature through large green parks open to the sky, unpolluted by the machine. His own formative years in the lush forests of the Swiss countryside, sketching and abstracting natural forms helped him observe and internalise the inherent logic in their geometry. Over the years, a deeper study of mathematical proportions of the human body led Le Corbusier to propose the Modulor as a standard for the human scale in architecture. This only further cemented his belief that there was no separate natural order and man-made order; man was a part of nature and therefore a part of the natural order as well. However, it was the spiritual aspect of city planning that fascinated Le Corbusier the most. After a life long study of natural forms, he was fully convinced that this Spirit was hidden in the geometries of nature. To him, it was essential that the twentieth century city employ this spiritual order as a means restore harmony between man, nature and the cosmos.
\end{abstract}

Resumen: Este trabajo conforma un intento para analizar y decodificar la aplicación de Le Corbusier en su comprensión excepcionalmente singular y compleja del orden del mundo natural en su obra maestra urbana - La Ciudad de Chandigarh. La firme creencia de Le Corbusier era que la arquitectura constituía una búsqueda personal de la verdad, una verdad establecida en la armonía orgánica de la naturaleza. Estaba convencido de que con el surgimiento de las máquinas en el siglo XIX, los lazos entre el hombre y la naturaleza se habían roto. Por el bien de la salud fisiológica y sicológica de los ciudadanos, sentía que era fundamental que las ciudades futuras se enfocaran en reconectar al hombre con la naturaleza a través de grandes parques verdes abiertos al cielo, sin ser contaminados por máquinas. Sus propios años de formación en los frondosos bosques del campo Suizo, esbozando y captando formas naturales lo ayudaron a observar e internalizar la lógica inherente en su geometría. Con el transcurso de los años, un estudio más profundo de proporciones matemáticas del cuerpo humano, llevaron a que Le Corbusier propusiera el Modulor como un estándar para la escala humana en arquitectura. Esto sólo consiguió consolidar aun más su creencia de que no había una separación entre el orden natural y el hecho por el hombre; el hombre era parte de la naturaleza y por lo tanto parte del orden natural también. Sin embargo, fue el aspecto espiritual de la planificación de la ciudad lo que más fascinó a Le Corbusier. Luego de un estudio de formas naturales a lo largo de la vida, se convenció por completo acerca de que este Espíritu estaba escondido en las geometrías de la naturaleza. Para él era primordial que la ciudad del siglo veinte empleara este orden espiritual como un medio para restaurar la armonía entre el hombre, la naturaleza y el cosmos.

Keywords: Chandigarh; City Planning; Capitol Complex; Modulor Man; Open Hand; Natural Order.

Palabras clave: Chandigarh; Planificación de la ciudad ; Capitol Complex; Modulor Man; Open Hand; Orden del Mundo Natural. 


\section{Introduction}

"I ask a simple question, an architectural question: what will become of the cities, New York, London, Paris, gigantic stretched to breaking point, full of mistakes and scorched by hot breath of the machine age? Tomorrow must provide an answer." 1

In 1951, Le Corbusier was given the opportunity to bring his answer from the drawing board to reality, the opportunity to design and construct a new capital for Punjab at the foothills of the Himalayas. The new capital, named Chandigarh, was meant to be an administrative city for the state of Punjab and was designed to eventually house up to 500,000 inhabitants, primarily refugees, who had fled to India during the violence of the India Pakistan partition in 1947. Le Corbusier aimed at providing all of Chandigarh's future residents with a pleasant social atmosphere along with all the amenities of modern living.

Appointed Chief Advisor for the project, Le Corbusier was engaged in generating the general and detailed urban layout, with the hierarchal arrangement of roads, the demarcation and placement of various zones, the styles of all buildings, various types of dwellings for the city's residents as well as the architecture of the Capitol Complex - the administrative center with ministries, High Court and a Governor's Palace. The architectural vision that he evolved for Chandigarh was an amalgam of the Mughal palaces of ancient India, the vernacular styles in Punjab, the rules of composition of Classical buildings of Europe that he admired as well as the learnings from his personal search for the Spirit of the natural world.

While critics often misunderstand the rigid orthogonal urban layout and the rugged concrete buildings of the Capitol because of their brutal physical appearance, the truth of the matter is that Le Corbusier's Chandigarh is rooted deep in his awareness of a universal natural order. Through the study of various aspects of the city's design, this paper will establish that Le Corbusier's design for Chandigarh was a masterful attempt to provide a New India with a city in equilibrium with the ancient spirit and the modern machine.

\section{Methodology}

In previous studies, Le Corbusier's theories and designs for cities, his use of symbols and his proposal for the Modulor have been studied in great depth and detail. The most significant study on the symbolism of Chandigarh is found in 'Le Corbusier: Ideas and Forms' by William J.R Curtis where he analyses and critiques Le Corbusier's vision for the city. An in-depth analysis of Le Corbusier's use of the Modulor and Golden Section in Chandigarh can be referred to in Klaus-Peter Gast's 'Le Corbusier, Paris-Chandigarh'. Sangeet Sharma, an architect working in Chandigarh, documents the history of Chandigarh and life in the city in the present day context. Chronicling his discussions with seven renowned architects who visit the city, Sharma wittily describes the forces that brought Chandigarh to life.

Le Corbusier's understanding of nature and the cosmic order has been analysed in Emma Dummett's thesis titled 'Green space and cosmic order: Le Corbusier's understanding of nature'. According to her, Le Corbusier's understanding of nature has within itself “...both evidence of a underlying, primordial order and a terrifying

\footnotetext{
${ }^{1}$ Corbusier, Le: “Introduction”, Boesiger, Willy (Ed.): Le Corbusier: oeuvre complète 1946-1952. Zurich: Éditions d'Architecture, 2006.
} 
morass of disorder; it was both a static image and a realm of experiential possibility.." ${ }^{\text {, }}$. Dummett's analysis provided a direction for this paper by pointing to Le Corbusier's holistic view of man's relationship with nature.

The present study focuses solely on the city of Chandigarh and aims to demonstrate how Le Corbusier's understanding of nature has both physical and spiritual manifestations in the city. For the purpose of this paper, only the designs that Le Corbusier fully realised in Chandigarh will be studied, thereby omitting his unbuilt designs for the Governor's Palace and several monuments in the pedestrian plaza of the Capitol Complex.

\section{Physical Manifestations of the Natural Order in Chandigarh}

For Le Corbusier, "the aim of taking man back to nature"3 was foremost in his designs for future cities. The most conspicuous route to achieve this was by interweaving the tangible dimensions of the natural world with the city's form.

\subsection{Open Space, gardens and greenery}

In the City of Tomorrow, Le Corbusier envisions the urban landscape of the future city as such: “ The whole city is a Park. The terraces stretch out over lawns and into groves. Low buildings of a horizontal kind lead the eye on to the foliage of the trees... Here is the CITY with its crowds living in peace and pure air, where noise is smothered under the foliage of green trees...Here, bathed in light, stands the modern city ...There are gardens, games and sports grounds. And sky everywhere, as far as the eye can see."4

This vision is there for all to see even today in Chandigarh where one is struck by the abundance of parks, gardens and open spaces in all parts of the city.

In a deliberate attempt to set Chandigarh apart from the squalor, congestion and poor levels of hygiene in the traditional Indian cities of the 1950s, Le Corbusier included extensive landscaping and verdure into the city's layout plan. Within the vast green belts, plentiful city parks and neighbourhood gardens, Le Corbusier wished for a vibrant public realm where the residents would have myriad opportunities for close contact with other humans as well as ample space for meditation and solitude. He envisioned people living an active and healthy life in the open green spaces where they were sheltered from the 'speed' of the modern city.

In Chandigarh, the continuous strips of green criss cross through the city's layout in the form of the Leisure Valley and special gardens at the city level, the central greens at the sector level, the small tot lots around which clusters of houses are arranged at the community level and individual courtyards for each dwelling at the smallest scale. Rows of trees line the roads, their species and shape determined by the orientation and function of the road in the hierarchy of V7 road network.

\footnotetext{
${ }^{2}$ Dummett, Emma: Green space and cosmic order: Le Corbusier's understanding of nature. Advisors: D. Weston, I. Boyd Whyte. Doctoral thesis, University of Edinburgh, 2007, p. 216

${ }^{3}$ Le Corbusier: The Marseilles Block. Sainsbury, Geoffrey (Trans.). London: Harvill Press,1953, p. 24. First published as Unité d'habitation Marseille, Le Point 38, November 1950 quoted in Green space and cosmic order: Le Corbusier's understanding of nature, p. 4.

${ }^{4}$ Corbusier, Le: The City of Tomorrow and Its Planning, Etchells, Frederick (Trans.). London: The Architectural Press, 1971. First published as Urbanisme, Editions Crès et Cie, Paris, 1924
} 


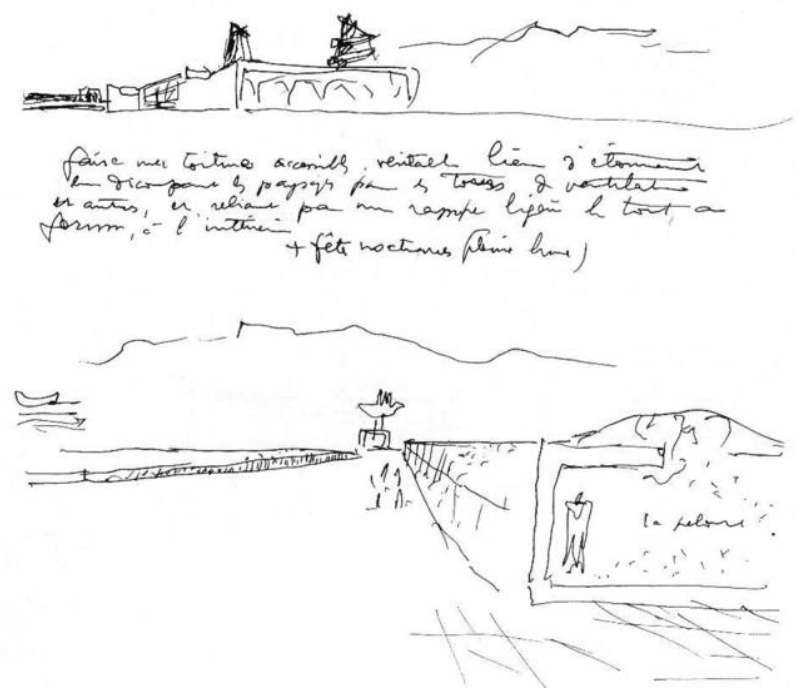

1. Le Corbusier's sketches of the vistas in the Capitol Complex from two different vantage points show the outline of the Himalayas drawn in the background.

While it is widely accepted that the Garden City movement played an influential role in Le Corbusier's design for abundant greenery within modern cities, his formative years in his hometown of La Chaux-de-Fonds in the Jura mountains of the Swiss countryside were the most profound influence. The experience of growing up in a well planned town with abundance of shared green space made him attempt to combine the benefits of life in the city with life in the rural countryside in his designs for Chandigarh.

Le Corbusier believed that by providing easy access to the basic pleasures such as sunlight, greenery and open space within the city, he could positively impact both the physiological and psychological aspects of man's well being. In the Radiant City, he talks of the future cities with their vast green spaces as those which will "enable the human spirit to draw strength from its active collaboration with the forces and beauties of nature."

\subsection{The Signature of the Himalayas}

A study of Le Corbusier's sketches of Chandigarh reveal one recurring theme - the silhouette of the majestic Himalayan skyline as the backdrop. Right from his initial sketches of the terrain to the final few of the Capitol Complex, the mountains reappear almost like they have become a part of the architectural composition.

Despite claiming to prefer the calm seas over the overwhelming mountains, "our loft wrinkles - the Alps, the Andes and the Himalayas ", had always enchanted Le Corbusier. Beginning from his project for his parents' lake house in 1925 to the Marseilles Unite, he made a wilful attempt to the lure the natural world into the private realm of the inhabitants. He follows this through in Chandigarh, only on a much larger urban scale.

A walk on the long vistas in the first phase of the city offer unobstructed views of the high hills of the Himalayas. However, the more scenic panorama is from the Leisure Valley - the most prominent of the green spaces in the city of Chandigarh that sprawls from the North-East to the South-West along a seasonal rivulet.

${ }^{5}$ Corbusier, Le: The Radiant City: elements of a doctrine of urbanism to be used as the basis of our machine-age civilisation. New York: Orion Press, 1967.

${ }^{6}$ Corbusier, Le: The Poem of the Right Angle. Hylton, Kenneth (Trans.). Paris: Fondation Le Corbusier and Editions Connivences, 1989. 
Here the spectacle of the mountains, framed by the the open skies and the vast expanse of greenery, prove to be a sanctuary from the fast moving machines of the modern city, a safe place to meditate and contemplate the natural world.

Even within the office blocks of the Secretariat building in the Capitol Complex, Le Corbusier finds ways to anchor man to the surrounding mountainous landscape. He explains his reasons for installing large coiling vertical ramps versus lifts in the building saying, “ Three thousand employees must climb forty metres once or twice a day. If we put in lifts they will have one or two overwhelming rush hours each day, and will contribute nothing at any other time...The motivating force is there to be taken in the feet and in the energy of each of the three thousand employees. In installing a beautiful ramp (and) making a magnificent viewing point onto the landscape, the city and the Capitol itself, we will give to those employees for ten months at least the possibility of a wonderful morning walk."7

Even at first glance, it becomes clear that Le Corbusier was finely attuned to the fact that despite advances of the industrial age, man had an innate desire for a meaningful connect with nature. It may seem that Le Corbusier greatly simplified this human desire and therefore only used nature in a mere instrumental manner through the abundance of greenery and framed panoramic mountain scenes at the urban scale. The truth however is that this was just the first step in his grand plan to restore the harmony between modern man and the natural world.

His own journey of understanding nature began in the lush forests of the Swiss countryside, observing, sketching and abstracting natural forms. After a life long study of the natural world, Le Corbusier was fully convinced that in order to create the ideal city, the elusive Spirit that animated all of nature should be deciphered and applied by man to his own creations.

"Nature presents itself to us as a chaos; the vault of the heavens, the shapes of lakes and seas, the outlines of hills. The actual scene which lies before our eyes, with its kaleidoscopic fragments and its vague distances, is a confusion. There is nothing there that resembles the objects with which we surround ourselves, and which we have created. Seen by us without reference to any other thing, the aspects of Nature seem purely accidental...But the spirit which animates Nature is a spirit of order; we come to know it. We differentiate between what we see and what we learn or know. ",

\section{Le Corbusier's Symbols and the Spirit of Chandigarh}

On the occasion of the inauguration of the city of Chandigarh in 1953, Pandit Jawaharlal Nehru, independent India's first Prime Minister said to the crowd gathered in front of the High Court, "Let this be a new town, unfettered by the traditions of the past... and expression of the nation's faith in the future." 9

\footnotetext{
7،“Trois milles employés doivent monter jusqu'à 40m. une ou deux fois par jour. Si on installe les ascenseurs ceux-ci auront une ou deux heures de pointe formidables, puis ne serviront plus à rien. / La force motrice est à prendre dans les pieds et dans l'énergie de chacun des 3000 employés. En installant une belle rampe faisant point de vue magnifique sur le paysage, sur la ville et sur les beautés du Capitol lui-même, on donne à ce personnel, pendant dix mois au moins la possibilité d'une promenade matinale magnifique." Le Corbusier to Jane Drew, 11 June 1952, FLC P2-11-175 as translated and quoted in Green space and cosmic order: Le Corbusier's understanding of nature, p. 110.

${ }^{8}$ The City of Tomorrow and Its Planning

${ }^{9}$ Singer, Milton: Semiotics of Cities, Selves and Cultures: Explorations in Semiotic Anthropology. Berlin: Walter de Gruyter, 1991
} 
In Chandigarh, Le Corbusier saw the need to create a city that spoke to the emerging spirit of a nascent independent nation in the post colonial world. The language he chose to communicate his vision for Chandigarh was a series of abstract symbols intricately woven into the urban fabric. As a Purist painter and sculptor, Le Corbusier was well-versed in the language of the abstract and had intimate knowledge of the deep meanings that could be conveyed through the simplest of forms.

Through his travels in India, he filled his sketchpad with wiry drawings of the rural Indian people, their lifestyles, the animals they domesticated and the landscape they inhabited. In the untouched countryside, he saw the peasants as a society of people living in the rural idyll that the industrialised societies of the west romanticised. Then on, the most challenging task in Chandigarh was to build a modern city that did not focus on the transient themes of its own period and the immediate past but remained in touch with the long-standing primeval ethos of India.

"At the end of 1951, in Chandigarh: the possibility of getting in touch with the essential joys of Hindu principles: a brotherhood of relationships between the cosmos and all living things: stars, nature, sacred animals, birds, monkeys, and cows, and in the villages, children, adults, and still active older people, the pond and the mango trees, all present and all smiling, poor but in proportion ",10

Initially, Le Corbusier wrote to Pandit Nehru hoping to learn of a few contemporary symbols that would easily express the ethical, socio-cultural and political ideologies of Indian culture ${ }^{11}$. When this search returned no results, he had no option but to rely on his own resources to find an appropriate set of symbols to represent the spirit of the natural world in a city of the second machine age.

A majority of the symbols he conceived for Chandigarh were abstract pictorial representations of man, his hands and foot prints, the native animals inhabiting the surrounding landscape- the birds in the sky, the domesticated bull on land, the fish, turtles, snakes living in the water and, most importantly, all of the natural world that he could perceive- the forces of nature, the mountains, the the sun, the stars and the moon. The idea of nature as sacred, was deep rooted in Le Corbusier's mind and it was this notion that impelled him to elevate familiar scenes of daily life to a quasi-religious status through his abstract symbolic language.

Le Corbusier's oeuvre of symbols were not limited to the two dimensional murals that adorned the walls, ceilings, tapestries and doorways. From the upturned arc of the recurrent parasol roof, that was a mere sculptural abstraction of the bull's horns to the more philosophically rooted Open Hand monument, Le Corbusier developed these symbols into a full fledged architectural language and conscientiously incorporated them into the three dimensional design of the buildings of the Capitol Complex and the city itself.

\subsection{The Rhythm of the Sun}

In the tropical climate of India, Le Corbusier saw the sun as the driving force of life where man's activities were dictated by the daily and annual rhythm of the solar cycle. Fascinated by this primal pulse of the natural world,

\footnotetext{
${ }^{10}$ Corbusier, Le: The Final Testament of Père Corbu.A Translation and Interpretation of Mise au point by Ivan Zaknic. Ivan Zaknic (Ed.). New Haven - London: Yale University Press, 1997

${ }^{11}$ Le Corbusier to Jawaharlal Nehru, 25 September 1961, FLC P1-6-264. Reproduced in Krustrup, Mogens: Porte email : Le Corbusier, Palais de l'Assemblée de Chandigarh = Emalje porten $=$ La porte emaillée $=$ The enamel door. Copenhagen: Arkitektens Forlag, Kunstakademiets Forlag, 1991 in Green space and cosmic order: Le Corbusier's understanding of nature, p. 164.
} 
Le Corbusier, in his poetry, compares the sun to a machine whose laws have been in place since time immemorial.

\author{
" Punctual machine turning \\ since time immemorial \\ engenders every instant of the \\ Twenty four hours cycle the gradation \\ the nuance the imperceptible \\ almost providing a rhythm.. ",12
}

While his sine curve symbol for the 24-hour cycle of the sun is commonly found in Chandigarh, Le Corbusier also united with the laws of the solar cycle, the play of light and shadow in his buildings. The parasol roof, brise soleil and the 'undulatories' found on the facades of his buildings in the Capitol Complex can be understood as functional symbols of the solar cycle, designed to naturally shade the interior spaces during the day while the sun moves through the sky.

A more symbolic representation of his fascination with the solar cycle is the pavilion of the Tower of Shadows. One of the few monuments to have been realised completely, its purpose is to map the path of the sun through shadows cast on the inside as well as the outside of its perforated walls. Oriented to face the ordinate points at 45 degrees off of the axes of the Capitol Complex, each wall and level of this Tower corresponds to the calculated angles of incidence.

The building of the Legislative Assembly played host to his most sincere effort to symbolise the daily as well as the annual rhythms of the sun. The fenestrations in the Tower of the Assembly Hall are a marriage of machine and myth. Le Corbusier's inspirations lay in the ancient Indian tradition of mapping the sun with large observatories called the Jantar Mantar. On visiting the Jantar Mantar in New Delhi, he commented, "They point the way; bind men to the cosmos ...the precise adaptation of forms and organisms to Sun, rain, air etc. "13. In a similar attempt, The Tower of the Assembly Hall was meticulously designed so that the window openings at the very top of the Tower would 'reflect the summer sun, to receive the winter sun and to reflect the sun of the equinoxes onto the interior surfaces of the hyperboloid'. Bathed in optimum natural light, the Assembly hall would create the ideal milieu for the representatives of the people to discuss affairs of national importance.

\title{
4.2 The Relevance of the Right Angle
}

The initial plan of Chandigarh, developed by American architect Albert Mayer and his assistant Mathew Novicki, was in a fan pattern with the curvilinear roads of the city located in the valley between the two seasonal rivulets. The most significant change made to this initial layout by Le Corbusier was his relocating the city's sectors within an orthogonal grid of $800 \mathrm{~m}$ x $1200 \mathrm{~m}$.

With the recurring orthogonal grid, Le Corbusier boldly resisted what was hitherto considered acceptable, that only curvilinear forms were natural. Corbusier's critics say his repeated use of the rigid right angle in the city plan was a forceful imposition of a machine-made order onto an organic world. Contrary to this commonly held

\footnotetext{
${ }^{12}$ The Poem of the Right Angle

${ }^{13}$ Tungare, Amit: Le Corbusier's Principles of City Planning and their Application in Virtual Environments. Advisor: Andonian, Greg. Masters thesis. Faculty of Graduate Studies and Research, School of Architecture Carleton University, Ottawa, Ontario, May, 2001, p. 67
} 
belief, Le Corbusier was an architect whose lifelong quest was to understand the underlying laws of natural world and embrace the universal harmony of nature in his architecture . A deeper reading of his designs for Chandigarh, allow us to see that he applied his learnings from nature to his designs for cities.

In his letters to his mother, Le Corbusier admits that openness of the site - "a limitless plain unroll(ing) itself over the hills and the foothills of the Himalayas ${ }^{\prime \prime 14}$ was what drew him to the project. The gentle slope at the foothills compelled him to develop the grid plan as a response to the vast site. The grid itself works in tandem with the natural features of the site because of its flexibility, adjusting when required to accommodate the large river valley running through the site.

The right angle itself was derived from a keen observation of nature. In the Poem of the Right Angle, Le Corbusier writes,

\section{" Erect on the terrestrial plain \\ of things knowable you \\ sign a pact of solidarity \\ with nature: this is the right angle...,, 15}

When he saw the horizon, he perceived it to form the right angle in conjunction with the vertical axis of gravitational force. The constant character of the right angle that kept the natural world in equilibrium intrigued him. To him, the right angle was a metaphor to express the underlying unity in man, nature and the cosmos.

\subsection{The Golden Section and the use of the Modulor}

Even early in his career, Le Corbusier perceived nature as ordered and organised within itself. What he was not able to resolve until later on was the role of man and his creations- the machine and modern buildings, in this natural world. Influenced by his work on regulating lines and proportional grids at the office of Peter Behrens in Berlin, he looked to mathematics and geometry for solutions to this problem.

It was during this search that Le Corbusier came across the works of Matila Ghyka, a Romanian mathematician and writer who published extensively on the origins and presence of the Golden Section in nature, art, architecture, music, and literature ${ }^{16}$. For Le Corbusier, the mathematics of the Golden Section seemed to hold a single answer to two separate questions under study- one was the search for a modular measurement for all components of a building and the second was a mathematical grounding that linked the proportions of the human body to the organising principles of nature.

The Modulor, which Le Corbusier described as a "range of harmonious measurements to suit the human scale, universally applicable to architecture and to mechanical things $" 17$, was born as a culmination of decades of research into these questions. By applying this system of "divine proportions" 18 from the Golden Section to the

\footnotetext{
14“"Une plaine illimitée s'appuyant sur des collines et un fond d'Himalaya." Le Corbusier to his mother, 12 March 1951, in Jenger, Jean (Ed.), Le Corbusier, Choix de Lettres. Berlin: Birkhäuser - Editions d'Architecture, 2002, p. 342 as quoted in Green space and cosmic order: Le Corbusier's understanding of nature, p. 37.

${ }^{15}$ The Poem of the Right Angle

${ }^{16}$ Cohen, J-L 2014: Le Corbusier's Modulor and the Debate on Proportion in France. Architectural Histories, 2(1): 23, pp. 114, DOI: http://dx.doi.org/10.5334/ah.by

17“"The Modulor", Le Corbusier: oeuvre complète 1946-1952

${ }^{18}$ Corbusier, Le: A Timely Book. Hendricks, Genevieve (trans.) as in Le Corbusier's Modulor and the Debate on Proportion in France
} 
built form, Le Corbusier wanted the human psyche to easily relate to the man-made and machine-made surroundings conspicuously at the physical level as well as latently at the primitive aesthetic and psychological level. With the Modulor, he ensured that buildings were designed to suit the scale of the human body and function as an extension of the limbs. The proportioning system was meant to affect the human mind at a much deeper level, where the inhabitant would intrinsically sense the beauty arising from the use of the Golden Section.

The repeated appearance of Le Corbusier's Modulor Man in the plazas and on the walls, tapestries and doors of Chandigarh is a small percentage of the symbolic value of the Modulor. For the city of Chandigarh, Le Corbusier envisaged a "full scale application of mathematics in building: three dimensional urbanism (on ground and in space)" ${ }^{\prime \prime}$. He imagined a city where the Modulor would be used as a measuring tool that influenced design at both large and small scales, "everything (from) pilotis, highways and roads, swimming pools, buildings, from top to bottom and in every object of interior, car parks... ",20.

The Capitol Complex in Chandigarh was by far Le Corbusier's grandest achievement. Even at this monumental scale, the Modular played a vital role during the design process. The entire Capitol Complex is located within a square with a dimension of 800 meters on each of its sides. Obelisks on four corners of this square marks the extreme boundaries of the Complex. Keeping in mind the proportions of the Modulor, Le Corbusier divided this large square further. He positioned his architectural masterpieces - the Secretariat, the High Court, the Assembly and the unbuilt Governor's Palace at specific points corresponding to the geometry of the Golden Section. While the relevance of this grandiose arrangement does not reveal itself at once to the human eye, Le Corbusier justified it saying, "the site is united with the imperceptible",21.



2. The Plan of the Capitol Complex as derived from the proportions of the Golden Section and the Modulor.

\footnotetext{
${ }^{19}$ Corbusier, Le: The Modulor. London: Faber and Faber, 1954 as quoted in Steyn, Gerald: Le Corbusier and the human body. Art Historical Work Group of South Africa, 2012

${ }^{20}$ Ibid.,

${ }^{21}$ Sharma, Sangeet: Corb's Capitol: (a journey through Chandigarh's architecture). w/o.pl. Abhishek Publications, 2009.
} 
From Klaus- Peter Gast's book Le Corbusier, Paris - Chandigarh, it is clear that the sculptural architectural forms of the Secretariat, the High Court and the Assembly buildings were all regulated with extensive use of the Modulor $^{22}$. For example, it is seen that the basic form of the Secretariat is based on the Modulor and Golden Section. Beginning with a simple rectangle, Le Corbusier divided it further into six proportional parts. He then derived a double square projected on the central axis and used the vertical axis dividing the lines between the square to establish the position of the wall within the rectangle. The system of proportioning and progressions further establish the positions of the pilotis, brise soleil on the facade, the location of dividing walls, room heights in sections as well as the dimensions of the open plans for the interiors. In Sangeet Sharma's book, Corb's Capitol: (a journey through Chandigarh's architecture), he narrates an incident where the Indian engineer on site was at a loss for why he could not use a beam 2' in depth in the High Court, forcing the architect in charge to explain that only a depth of $1^{\prime}-71_{2}$ " or $2 '-1 \frac{1}{2}$ " would suit the dimensions of the Modulor ${ }^{23}$.

In the Edict of Chandigarh, Le Corbusier expresses his deep belief in the Modulor, its sacrosanct goals and explains his ambitions to the future citizens, "The city of Chandigarh is planned to human scale. It puts in touch with the infinite cosmos and nature. It provides us with places and buildings for all human activities in which the citizens can live a full and harmonious life. Here the radiance of nature and heart are within our reach.",24

\subsection{The Anthropomorphic city plan}

Even prior to the development of the Modulor, Le Corbusier thought of man as a symbolic representation of the entire universe; a thought that could be traced back to the times of Da Vinci's Vitruvian Man. Since his early years, he had shown a keen interest in the study of biology and it was this interest that influenced his ideas for anthropomorphic future cities. To him, cities and towns were "biological phenomena" 25 and he drew a direct likeness between the city form and the human body. In his mind, the city had a head, a heart, lungs and a circulatory system that were as essential to the city as they were to the human body. Extending this analogy further, he contended that if the city was left uncared for it would lose its vitality and energy deteriorating to the extent of disarray.

Le Corbusier had extensively applied this similarity between the city and the human body in his previous projects such as his design for the Radiant City. In the City of Tomorrow, he refers to the parks and gardens as the "lungs" of a city and conveys the revolutionary idea of a living, breathing city, thus forever transforming the way people look at man's most complex creation- the city. In his sketches, he anthropomorphised the dwellings by drawing a single eye on each of them. He did this because he pictured the built form of the dwelling taking on the human persona of its residents, imagining each building to be gazing peacefully at the surrounding landscape.

Inspired by the rationality and harmony in the functioning of systems of the human body, Le Corbusier's Chandigarh was a symbol of the organising principles that nature had created for the human body. While Mayer's and Novicki's plan of Chandigarh also indicated the head and body of the city, it was Le Corbusier's

\footnotetext{
${ }^{22}$ Gast, Klaus-Peter: Le Corbusier, Paris-Chandigarh. Basel, Birkhaüser, 2000

${ }^{23}$ Corb's Capitol: (a journey through Chandigarh's architecture)

${ }^{24}$ Edict of Chandigarh, Chandigarh: The City Beautiful, The official website of the Chandigarh Administration, http://chandigarh.gov.in/knowchd_edict.htm accessed on $1^{\text {st }}$ June,2015

${ }^{25}$ Corbusier, Le: Concerning Town Planning. Entwistle, Clive (trans.). London: The Architectural Press, 1947, p. 11. First published as Propos d'Urbanisme, Paris: Editions Bourrelier et Cie, 1946 as quoted in Green space and cosmic order: Le Corbusier's understanding of nature, p. 81
} 
deeper understanding of this symbolism that allowed him to connect the two separate parts. He envisaged the city of Chandigarh with the Capitol Complex, Sector 1 as the head, the City Center Sector-17 became the heart, the Leisure valley and other green open spaces were the lungs providing a breath of fresh air to the city's residents, the cultural and educational institutions stood for the intellect, the industrial areas formed the viscera and lastly the hierarchy of roads in the V7 network acted as the circulatory system of the body.

His parallel of the city and the human body did not end at this scale; he even looked at the cell for inspiration. The cells, basic building blocks of all living things, provide order and structure to the whole body. He saw the cell as a self-sufficient organism, interacting with other cells to ensure the proper and smooth functioning of the body. Analogous to the cell, each sector in the urban layout of Chandigarh city was self-sufficient, having shops, schools, health centres and places of worship and recreation within itself. Similar to the cells in the natural world, each sector had its designated role to play in the smooth functioning of the whole - the city. This analogy to the cell justifies his need to standardise the dimensions of the sector and reproduce it multiple times to fill the city's layout plan.

While the large city has no obvious physical similarities to a human's body, it remains symbolic of the order of the natural world. In the words of the architect himself, "If the creation is ordered, it lasts throughout time and remains an object of admiration in every mind. This is the work of art, the human creation which, while no longer bearing any of the evident aspects of Nature, yet submits to the same laws. ${ }^{26}$

The immense thought put into the anthropomorphic design of Chandigarh makes the city itself a symbol. By applying the laws of the human body to the ordering of human habitation, Le Corbusier attempted to infuse the city with a primeval spirit that was until then buried deep within each individual.

\subsection{The Spirit of the Open Hand}

"The Open hand is the only political act of my life..The Hand is open to give and receive. It is a sign of optimism in this world of catastrophe. ${ }^{27}$

The Monument of the Open Hand crowns the Pit of Contemplation at the far north of the Capitol Complex. The Pit is 5 meters deep and consists of two amphitheaters, a speaker's platform and ramp that leads up to ground level. From its sunken depth, every perspective is dominated by the 28 meters tall Open Hand sculpture. The abstract human hand sculpture is placed atop a slender column acting as the axis of the ball bearings on which the sculpture rotates.

In a video interview, Le Corbusier describes this monument as a place to discuss the affairs of the people without the interference of those in power, much like the Greek democracies of the past. The two amphitheaters represent the idea that there would always be two sides to any debate. Similar to a tree whose branches swayed with the wind, the Open Hand was designed "like a weather cock, not to show the incertitude of ideas, but to indicate symbolically the direction of the wind (that is the state of affairs). ${ }^{, 28}$

\footnotetext{
${ }^{26}$ The City of Tomorrow and Its Planning

${ }^{27}$ Recorded video interview of Le Corbusier, https://www.youtube.com/watch?v=UmcR9jU6SPw, accessed on $1^{\text {st }}$ June, 2015

28 “ The Open Hand", Le Corbusier: oeuvre complète 1946-1952.
} 


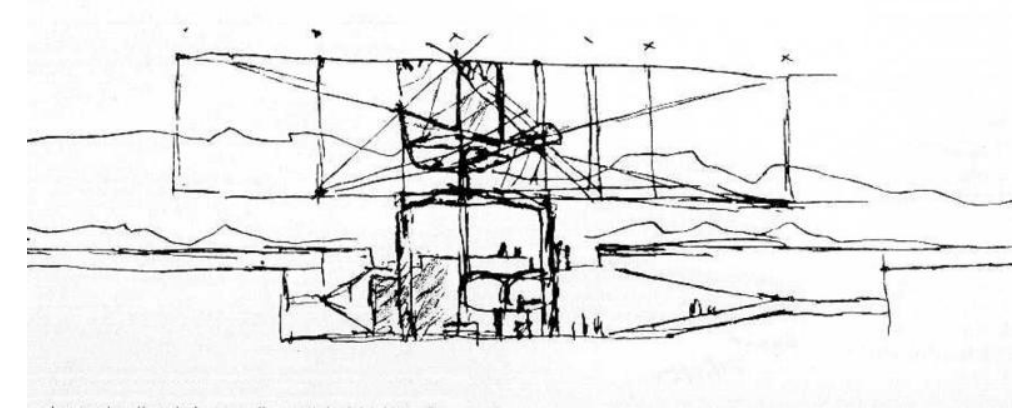

3. Le Corbusier's sketch of the Open Hand Monument superimposed with the proportioning lines of the Golden Section and the Modulor. The outline of the Himalayas are drawn in the background.

The inspiration for the form has been debated innumerable times- "The reverent see in the Open Hand a pancultural significance, a cross between a Buddhist gesture for dispelling fear and a hovering Picasso Peace Dove. ${ }^{, 29}$ However, the most intriguing answer is from Xavier Monteys who perceives the Open Hand as a series of mountain peaks ${ }^{30}$. As noted before, Le Corbusier was particularly fascinated by the mountain peaks whether they were the Alps, where he first drew their silhouettes, the Andes, where he perfected his drawing of the Open Hand or the Himalayas, where his vision was finally brought to life. Monteys suggests that Le Corbusier himself was only subconsciously aware of this resemblance as he spontaneously drew the form of the Open Hand with the Himalayas as a backdrop. He goes on to question whether the Open Hand was in reality a "Monument to the men or a Monument to the Mountain? ${ }^{, 31}$.

While the symbol of the Open Hand has appeared time and again in Le Corbusier's previous sketches and paintings, the proportions of the Open Hand Monument in Chandigarh were subject to the Golden Section, a mathematical law that he related to the universal order. In a sketch dating $6^{\text {th }}$ April, 1952, the Open Hand Monument is shown superimposed by the proportioning rectangles of the Golden Section and the Modulor ${ }^{32}$. While it is certain that Le Corbusier wished for the Open Hand to follow the sound aesthetic principles derived from the Modulor, this rigorous use of the Modulor even in this stand-alone sculpture can be seen as a reflection of his deep-rooted need to follow the laws of a universal natural order.

At the end of his life long search, Le Corbusier still remained doubtful if he had been able to unearth the hidden laws that governed the natural world. However, what he was unequivocally sure of was that whatever be these elusive laws, the end result was always universally harmonious. The Open Hand Monument was Le Corbusier's

\footnotetext{
${ }^{29}$ Curtis, William J.R. : Le Corbusier: Ideas and Forms. London - New York: Phaidon Press Limited, 2001. First published in 1986

${ }^{30}$ Monteys, Xavier: Alpes, Andes, Himalaya. Massilia: anuario de estudios lecorbusierianos, 2004 bis, p. 136-143. http://hdl.handle.net/2099/9268

31 “Monumento a los hombres o a la Montãna?” translated from Alpes, Andes, Himalaya

${ }^{32}$ Le Corbusier: oeuvre complète 1946-1952.
} 
call to arms, a timeless symbol reminding not only the people of Chandigarh, but the entire human race to rise above the "feelings of anguish and disharmony which separate mankind, and so often create enemies., 33

"I let the others find a solution now, for it's a tragic moment!" 34

With this altruistic gift, Le Corbusier urges the people to set off on their own search for the natural order, a search that would no doubt result in an understanding of themselves, their surroundings and also lead the way for a state of harmony and accord.

\section{Image Sources}

Corbusier, Le: "Chandigarh, the new capital of Punjab", Boesiger, Willy (Ed.): Le Corbusier: oeuvre complète 1957-1965. Zurich: Éditions d'Architecture, 2006.

Sketch by Author

Corbusier, Le: “The Open Hand”, Boesiger, Willy (Ed.): Le Corbusier: oeuvre complète 1946-1952. Zurich: Éditions d'Architecture, 2006.

\section{Bibliography/references}

Boesiger, Willy (Ed.): Le Corbusier: oeuvre complète 1946-1952. Zurich: Éditions d'Architecture, 2006.

Cohen, J-L 2014: Le Corbusier's Modulor and the Debate on Proportion in France. Architectural Histories, 2(1): 23, pp. 1-14, DOI: http://dx.doi.org/10.5334/ah.by

Corbusier, Le: The City of Tomorrow and Its Planning, Etchells, Frederick (Trans.). London: The Architectural Press, 1971. First published as Urbanisme, Editions Crès et Cie, Paris, 1924

Corbusier, Le: The Radiant City: elements of a doctrine of urbanism to be used as the basis of our machine-age civilisation. New York: Orion Press, 1967.

Corbusier, Le: The Poem of the Right Angle. Hylton, Kenneth (Trans.). Paris: Fondation Le Corbusier and Editions Connivences, 1989.

Corbusier, Le: The Final Testament of Père Corbu.A Translation and Interpretation of Mise au point by Ivan Zaknic. Ivan Zaknic (Ed.). New Haven - London: Yale University Press, 1997.

Curtis, William J.R.: Le Corbusier: Ideas and Forms. London - New York: Phaidon Press Limited, 2001. First published in 1986.

Dummett, Emma. Green space and cosmic order: Le Corbusier's understanding of nature. Advisors: D.

Weston, I. Boyd Whyte. Doctoral thesis, University of Edinburgh, 2007

Gast, Klaus-Peter: Le Corbusier, Paris-Chandigarh. Basel, Birkhaüser, 2000

Monteys, Xavier: Alpes, Andes, Himalaya. Massilia: anuario de estudios lecorbusierianos, 2004 bis, p. 136-143. http://hdl.handle.net/2099/9268

Sharma, Sangeet: Corb's Capitol: (a journey through Chandigarh's architecture). w/o.pl. Abhishek Publications, 2009.

Singer, Milton: Semiotics of Cities, Selves and Cultures: Explorations in Semiotic Anthropology. Berlin: Walter de Gruyter. 1991.

\footnotetext{
33 Ibid.,

${ }^{34}$ Recorded video interview of Le Corbusier, https://www.youtube.com/watch?v=UmcR9jU6SPw, accessed on $1^{\text {st }}$ June, 2015
} 
Tungare, Amit: Le Corbusier's Principles of City Planning and their Application in Virtual Environments. Advisor: Andonian, Greg. Masters thesis, Faculty of Graduate Studies and Research, School of Architecture Carleton University, Ottawa, Ontario, May, 2001

Edict of Chandigarh, Chandigarh: The City Beautiful, The official website of the Chandigarh Administration, http://chandigarh.gov.in/knowchd_edict.htm accessed on 1st June,2015

Recorded video interview of Le Corbusier, https://www.youtube.com/watch?v=UmcR9jU6SPw , accessed on 1st June, 2015 